\title{
Particulate Organic Matter and Soil Nitrogen Availability in Urban Landscapes
}

\author{
Bryant C. Scharenbroch and John E. Lloyd
}

\begin{abstract}
Toward developing nitrogen management in amenity tree care, we studied soil organic matter, microbial biomass, and carbon and nitrogen mineralization in an attempt to characterize the plant available nitrogen under a variety of landscape management conditions. Fine particulate organic matter (POM) fractions were significantly correlated with microbial biomass, carbon mineralization, and nitrogen mineralization ( $\mathrm{R}^{2}$ values ranging from 0.42 to 0.89 ). These urban landscapes were assigned a site quality index based on landscape age and management practices. Fine POM, microbial biomass $\mathrm{N}$, and $\mathrm{N}$ mineralization were significantly and positively correlated with the site quality index $\left(\mathrm{R}^{2}\right.$ values of 0.86 , 0.90 , and 0.84 , respectively). We propose that with refinement and further testing, a fine POM measurement can be used to accurately predict soil nitrogen availability in urban landscapes. This research shows that urban landscapes are quite variable in terms of nitrogen availability. As a result of this variability, we recommend that urban landscapes be assessed on a per-site basis for proper nitrogen management.
\end{abstract}

Key Words. Microbial biomass and activity; nitrogen mineralization; particulate organic matter; soil nitrogen availability.

Soil nitrogen availability is a chief concern of managers of trees in urban landscapes. Amenity tree fertilization practices are specified by the American National Standards Institute, ANSI A300 for Tree Care Operations-Tree, Shrub, and Other Woody Plant Maintenance-Standard Practices (Fertilization) (2001). Standard 7.2.1 states that the reason for fertilization is to "supply nutrients determined to be deficient." According to objective 7.2.6, soil and/or foliar analysis should be used to determine the need for fertilizer. Standard 8.1.2 states that in the absence of a soil and/or foliar analysis, a 3:1:2 or 3:1:1 fertilizer ratio should be used, and these ratios should be adjusted based on local knowledge, age, and/or condition of the plant, soil, and environmental conditions. Standard 8.1.4 states that slow-release fertilizers should be applied at rates between 1000 and $2000 \mathrm{~kg} \mathrm{~N}^{-1}$ ( 2 to $4 \mathrm{lb} \mathrm{N} 1000 \mathrm{ft}^{-2}$ ) per application not to exceed $3,000 \mathrm{~kg}$ $\mathrm{N} \mathrm{ha}^{-1}$ (6 lb N $1000 \mathrm{ft}^{-2}$ ) annually.

Plant health care (PHC) and integrated pest management (IPM) programs have promoted site-specific prescription fertilization for the maintenance and establishment of urban trees (Smith et al. 2002). The ANSI standards recognize the need for inclusion of extant soil nitrogen in fertilization recommendations, but soil nitrogen analysis is only suggested and not required (TCIA 2001). By providing specific fertilizer ratios, types, and amounts without consideration of soil nitrogen availability status, Standards 8.1.2 and 8.1.4 endorse nitrogen fertilization without soil assessment. Research that details the soil nitrogen variability among types of urban landscapes is significant because it provides data to support the need of required soil assessment before fertilization.
Because a standard soil nitrogen availability index does not currently exist; urban landscape fertilization is routinely performed without knowledge of existing soil nitrogen conditions (Beverly et al. 1997; Osmond and Platt 2000). Plant health care, integrated pest management, and the ANSI Standards serve as the foundation for prescription tree fertilization, but their use and value could be increased with a practical and accurate soil nitrogen assessment. To be practical, nitrogen assessments must be affordable, convenient, and easy to interpret. Accurate nitrogen assessments must also be highly correlated with established soil nitrogen availability indices and plant response.

The accuracy and practicality of common soil nitrogen assessment methods have been reviewed (Kopinga and van den Burg 1995; Doran and Jones 1996; Scharenbroch and Lloyd 2004). Total soil nitrogen in urban landscapes ranges from 1.10 to $6.07 \mathrm{~g} \mathrm{~kg}^{-1}$ (51 to $214 \mathrm{lb} \mathrm{N} 1000 \mathrm{ft}^{-2}$ ) (Roberts and Roberts 1984; Beyer et al. 1995; Pouyat et al. 2002). However, much of the total soil nitrogen is found in forms unavailable to plants; thus, measurements of total soil nitrogen tend to overestimate plant available nitrogen (Mulvaney and Khan 2001). Studies that have measured extractable mineral nitrogen found ranges of 45 to $1500 \mu \mathrm{g} \mathrm{g}^{-1}$ (0.55 to 5.7 lb N $1000 \mathrm{ft}^{-2}$ ) in urban environments (Roberts and Roberts 1984; Goldman et al. 1995; Zhu and Carreiro 1999). Measurements of soil mineral nitrogen are inherently variable as a result of environmental factors such as moisture, temperature, and microbial activity (Khan et al. 2001; Mulvaney and Khan 2001). Also, mineral nitrogen measurements include nitrogen available for uptake by plants and soil microorgan- 
isms (Evangelou 1998). Mineral nitrogen measurements may have value when used in conjunction with biologic indices of soil nitrogen availability (Drinkwater et al. 1996; Qafoku et al. 2001)

Indices of soil microbial biomass or activity such as nitrogen mineralized by microbial enzymes over a given timespan are considered more accurate soil nitrogen availability indices than extractable mineral nitrogen (Stanford and Smith 1972; Keeney 1982; Molina et al. 1983; Drinkwater et al. 1996; Knoepp et al. 2000; Verchot et al. 2001; Anderson et al. 2002; Picone et al. 2002). Measurements of microbial biomass and activity have been used to monitor decomposition and mineralization processes from urban soils (Beyer et al. 1995; Pouyat et al. 1995; Beyer et al. 1996; Carreiro et al. 1999). Nitrogen mineralization in urban soils ranged from 0.35 to $2.08 \mu \mathrm{g} \mathrm{g}^{-1} \mathrm{~d}^{-1}$ (0.02 to $0.10 \mathrm{lb} \mathrm{N} 1000 \mathrm{ft}^{-2} \mathrm{~d}^{-1}$ ) (White and McDonnell 1988). Although considered more accurate, current biologic nitrogen assessments are not used because they are rarely offered by commercial soil testing laboratories (Picone et al. 2002).

Soil organic matter is a critical determinant of soil physical, chemical, and biologic properties and is often proposed as an index of soil nutrient status (Tisdale and Oades 1982; Burger and Pritchett 1984; Fox et al. 1986; Sikora and Stott 1996; McLaughlin et al. 2000) and nitrogen availability (McLaughlin et al. 2000; Ding et al. 2002). Soil organic matter assessments are commonly offered at relatively low costs by soil commercial testing laboratories (Scharenbroch and Lloyd 2004). Soil organic matter decomposition creates a recalcitrant component that is relatively inactive in nitrogen mineralization (Chefetz et al. 2002; Graham et al. 2002). Recalcitrant organic matter fractions have been found to occupy as much as $60 \%$ to $70 \%$ of the total soil organic matter (Schnitzer 1986). Turnover rates of 1500 years have been estimated for the stable soil organic matter components (Campbell 1978; Parton et al. 1987). Total soil organic matter changes are slow (Sikora and Stott 1996); thus, seasonal variations in soil nitrogen are difficult to detect with total soil organic matter assessments.

An active soil organic matter component, particulate organic matter (POM), has been found to relate soil organic matter dynamics (Paul 1984; Parton et al. 1987; Powlson et al. 1987; Cambardella and Elliott 1992; Janzen et al. 1992; Paustian et al. 1992; Biederbeck et al. 1994; Gregorich et al. 1994; Magid et al. 1996; Chan 1997; Alvarez et al. 1998; Janzen et al. 1998; Six et al. 1998; Graham et al. 2002; Franzlubbers and Stuedemann 2003; Salas et al. 2003). Particulate organic matter has been found to be positively correlated with soil microbial nitrogen and nitrogen mineralization (Alvarez et al. 1998; Sohn Lopez-Forment 2000; Duriancik 2001; Stinner et al. 2002; Franzlubbers and Stuedemann 2003). Particulate organic matter is indicative of nitrogen availability; but POM has yet to be examined in urban soils.

The first goal of this research was to assess the spatial differences in soil nitrogen across an array of urban landscape types. Our hypothesis was that soil nitrogen pools will be significantly different among urban landscapes, thus emphasizing the need for site-specific soil nitrogen assessment before fertilization. Our second goal was to identify a practical and accurate soil nitrogen assessment method for potential use by urban landscape managers. We propose that POM is an accurate predictor of microbial biomass nitrogen and nitrogen mineralization rates across an array of urban landscapes. If POM measurements are well correlated with microbial biomass and activity, then POM measurements have potential to be used as accurate and practical means for urban landscape managers to assess soil nitrogen availability. If POM is found to be indicative of soil nitrogen availability, it can then be examined with indices of plant quality to refine current nitrogen fertilization recommendations for urban landscapes.

\section{MATERIALS AND METHODS}

Study sites were selected within the cities of Moscow, Idaho, $46^{\circ} 44^{\prime} \mathrm{N}$ and $116^{\circ} 58^{\prime} \mathrm{W}$ and Pullman, Washington, $46^{\circ} 43^{\prime} \mathrm{N}$ and $117^{\circ} 11^{\prime} \mathrm{W}$. Human population density in Moscow, Idaho, is 882 people $\mathrm{km}^{-2}$ (341 people mile ${ }^{-2}$ ) and 1069 people $\mathrm{km}^{-2}$ (412 people mile ${ }^{-2}$ ) in Pullman, Washington. All urban soils in this study had a silt loam texture with a range of $6 \%$ to $26 \%$ clay, $54 \%$ to $67 \%$ silt, and $13 \%$ to $33 \%$ sand (Scharenbroch et al. 2005). The soils are described as Palouse silt loam with $7 \%$ to $25 \%$ slopes (USDA 1980, 1981). The soils were formed in loess and volcanic ash and are well to moderately well-drained. The sample region is described as gently sloping to moderately steep silt loam on uplands. The elevation is approximately $790 \mathrm{~m}(2607 \mathrm{ft})$. The average annual precipitation is 530 to $840 \mathrm{~mm}$ (21.2 to 33.6 in); during the study years of 2002 to 2003 , precipitation was $760 \mathrm{~mm}$ (30.4 in) (Patten 2003). The average frost-free season is 90 to 140 days. During 2002 and 2003, the mean air temperature was $12.1^{\circ} \mathrm{C}\left(53.8^{\circ} \mathrm{F}\right)$ and the temperature in the top $10 \mathrm{~cm}$ of soil was approximately $10.1^{\circ} \mathrm{C}\left(50.2^{\circ} \mathrm{F}\right)$ (Patten 2003).

Soil samples were collected nine times in 2002 (4/17, 5/01, $5 / 15,5 / 29,6 / 12,6 / 26,8 / 03,9 / 05$, and 10/03) and nine times in $2003(4 / 17,5 / 01,5 / 15,5 / 29,6 / 12,6 / 26,8 / 03,9 / 05$, and $10 / 03$ ). We sampled residential yards greater than 50 years old, residential yards less than 10 years old, mulched beds greater than 10 years old, mulched beds less than 3 years old, street tree plantings, and park trees (Table 1). These urban landscapes were assigned a site quality index (SQI) based on landscape age and management practices: SQI = mean landscape age + fertilization value $(0,1$, or 2$)+$ irrigation value $(0,1$, or 2$)+$ grass clipping value $(0,1$, or 2$)+$ mulching value $(0,1$, or 2$)$. For example, sites fertilized twice annually 


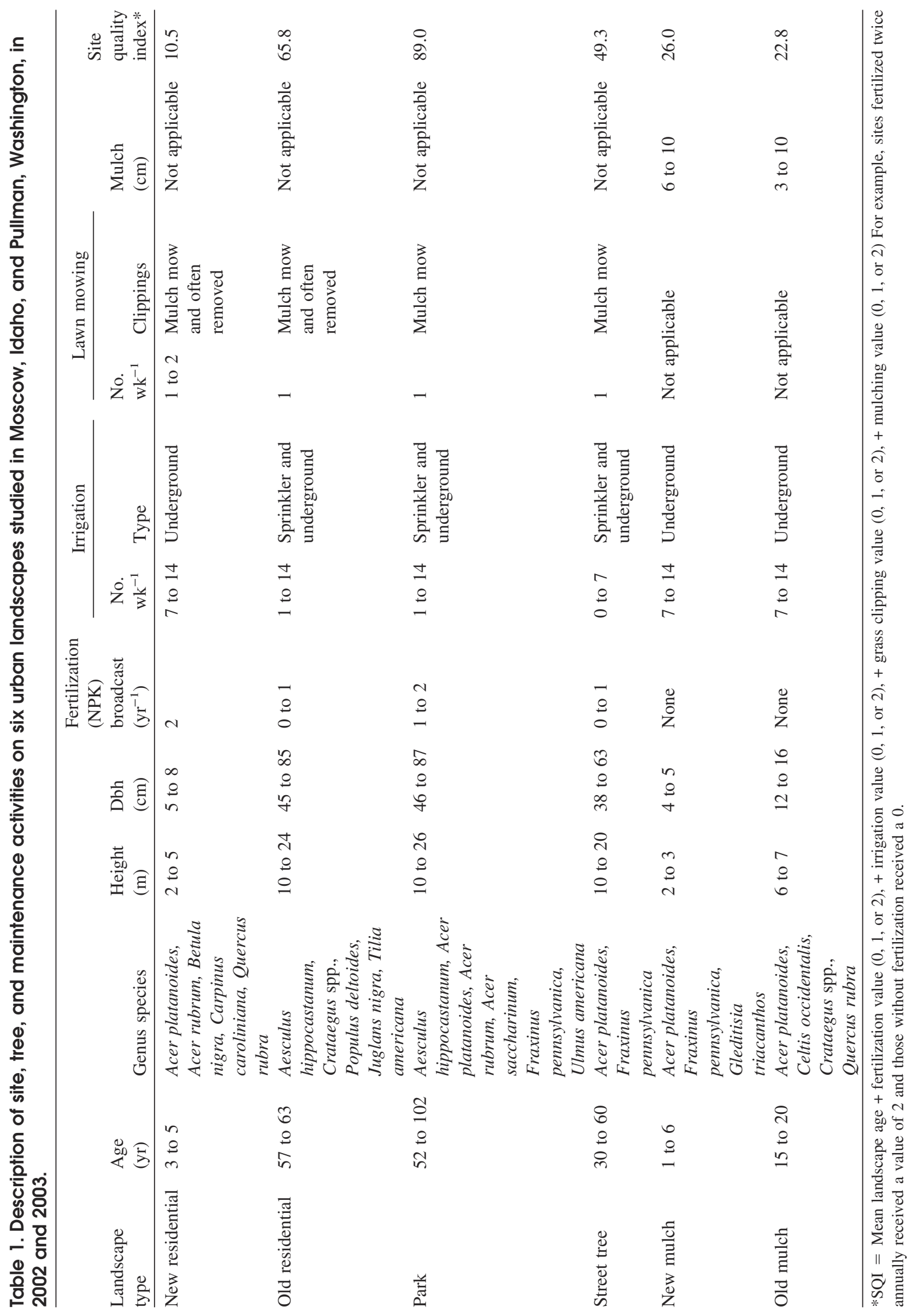


received a value of 2 and those without fertilization received a 0 . Each of the six landscape types had four plots with two subplots each for a total of 48 sample points at each sampling date. Site, vegetation, and soil management history were attained for each site by personal interviews. Management practices such as fertilization and irrigation were monitored throughout the study. Four $2.5 \mathrm{~cm}$ ( 1 in) diameter by $15 \mathrm{~cm}$ (6 in) deep cores were collected within drip lines of trees. Soils were passed through a $6 \mathrm{~mm}(0.24 \mathrm{in})$ wire screen to remove stones and organic debris while minimizing the impact on biologic measurements (Ross 1992). After sieving, soil samples were stored at $4^{\circ} \mathrm{C}\left(39.2^{\circ} \mathrm{F}\right)$ until processed.

Soil bulk density was determined from soils collected on 17 April 2002. Soil textural analysis was performed by Midwest Laboratories, Inc. (Omaha, NE) with soils collected on 17 April 2002. Gravimetric soil moisture content was calculated from soil sample weights before and after drying at $105^{\circ} \mathrm{C}\left(221^{\circ} \mathrm{F}\right)$ for 24 hours (Gardner 1965). Soil subsamples were adjusted to $40 \%$ water-holding capacity for further analysis (Kaiser et al. 1992; Joergensen and Mueller 1996).

A modified soil fumigation-extraction method (Brookes et al. 1985; Sparling et al. 1990; Kaiser et al. 1992; Cabrera and Beare 1993; Joergensen and Mueller 1996) was used to determine microbial biomass nitrogen (MBN). Soil subsamples were fumigated with ethanol-free chloroform for 5 days, extracted with $0.5 \mathrm{M} \mathrm{K}_{2} \mathrm{SO}_{4}$, and extractable nitrogen was reduced to $\mathrm{NH}_{4}{ }^{+}$for colorimetric analysis at $650 \mathrm{~nm}$. Unfumigated soil subsamples were analyzed for extractable nitrogen. Microbial biomass nitrogen was represented by the difference in nitrogen between the fumigated and the unfumigated samples using an extraction efficiency factor of $\mathrm{K}_{\mathrm{EN}}=0.54$ (Joergensen and Mueller 1996). Soil respiration, expressed as potentially mineralizable carbon (PMC), was attained with 20-day soil incubations using $\mathrm{NaOH}$ traps. Carbon dioxide sequestered by $\mathrm{NaOH}$ was precipitated with $\mathrm{BaCl}_{2}$ followed by $0.25 \mathrm{M} \mathrm{HCl}$ titration to a phenolphthalein endpoint (Anderson and Domsch 1978; Parkin et al. 1996; Duriancik 2001). Potentially mineralizable nitrogen (PMN) was determined using 20-day aerobic incubations followed by a nitrogen extraction with $0.5 \mathrm{M} \mathrm{K}_{2} \mathrm{SO}_{4}$ and colorimetric analyses (Drinkwater et al. 1996). Mineral nitrogen $\left(\mathrm{NH}_{4}{ }^{+}, \mathrm{NO}_{2}{ }^{-}\right.$, and $\mathrm{NO}_{3}{ }^{-}$) before incubation was subtracted from nitrogen mineralized during the 20 days.

Mineral nitrogen (MIN) and dissolved organic nitrogen (DON) were determined by extraction with $0.5 \mathrm{M} \mathrm{K}_{2} \mathrm{SO}_{4}$ followed by colorimetric analyses at 650 nanometers for ammonium $\left(\mathrm{NH}_{4}^{+}\right)$, nitrate $\left(\mathrm{NO}_{3}{ }^{-}\right)$, nitrite $\left(\mathrm{NO}_{2}{ }^{-}\right)$, and dissolved organic nitrogen (Cabrera and Beare 1993; Sims et al. 1995; Rice et al. 1996; Duriancik 2001). Ammonium concentrations in filtrate extracts were determined. A reduction with Devarda's alloy and sulfuric acid was used to reduce nitrate and nitrate to ammonium. Mineral nitrogen was represented by $\mathrm{NH}_{4}^{+}+\mathrm{NO}_{2}{ }^{-}+\mathrm{NO}_{3}^{-}$in extracts; and alkaline persulfate digestion under pressure was used to determine total nitrogen in filtrate extracts. The difference between total extractable nitrogen and mineral nitrogen $\left(\mathrm{NH}_{4}{ }^{+}+\mathrm{NO}_{3}{ }^{-}+\mathrm{NO}_{2}{ }^{-}\right)$was represented as DON.

Particulate organic matter fractions were isolated by a modified particle size fractionation method (Elliot and Cambardella 1991; Cambardella and Elliot 1992, 1993; Six et al. 1998; Gill et al. 1999; Bayer et al. 2001; Six et al. 2002; Salas et al. 2003). Soil samples were shaken for 15 hours with sodium hexametaphosphate $\left(\mathrm{NaPO}_{3}\right)$ and then passed through a series of nested sieves. The organic matter collected on the 2,000, 250, and 53- $\mu \mathrm{m}$ sieves was considered litter SOM (ISOM), coarse POM (cPOM), and fine POM (fPOM), respectively. Mineral-associated SOM (maSOM) passed through the $53-\mu \mathrm{m}$ sieve and was determined by $\mathrm{maSOM}=$ total SOM - ISOM - fPOM - cPOM.

Loss on ignition (LOI) and automated dry combustion methods were used to determine organic matter, nitrogen, and carbon in each size fraction. Once fractionated, samples were oven dried at $105^{\circ} \mathrm{C}\left(221^{\circ} \mathrm{F}\right)$, homogenized, and weighed. Subsamples of the coarse and fine POM fractions were analyzed for total nitrogen and carbon content by dry combustion with an automated gas combustion analyzer (Vario Max CNS, Mt. Laurel, NJ). Values of nitrogen and carbon in the POM fractions were expressed as $\mathrm{g} \mathrm{N}$ or $\mathrm{C} \mathrm{m}^{-2}$ or as a $\mathrm{C} / \mathrm{N}$ ratio of those fractions. The remaining portions of the $1 \mathrm{SOM}$, cPOM, and fPOM fractions were dried at $105^{\circ} \mathrm{C}\left(221^{\circ} \mathrm{F}\right)$ and burned at $360^{\circ} \mathrm{C}\left(680^{\circ} \mathrm{F}\right)$ for 6 hours to determine ash weight (Schulte et al. 1991; Sikora and Stott 1996). Accuracy of the loss on ignition method was checked with linear regression of urban landscape mean values from all sample dates of the fPOM carbon content determined by automated dry combustion and $\mathrm{g}$ fPOM m${ }^{-2}$ determined by LOI $\left(\mathrm{R}^{2}=0.90\right)$. Linear regressions were also performed with values of total SOM determined by the LOI and the Walkley-Black method (Midwest Laboratories, Omaha, NE) with samples collected on 17 April 2002, 3 October 2002, 11 April 2003, and 10 October 2003 , yielding $\mathrm{R}^{2}$ values of $0.69,0.77,0.86$, and 0.89 .

The design structure was a repeated measure over time in a nested whole plot. The experimental variables measured were nitrogen pools, the treatments were the urban landscapes, and the plots were individual trees within urban landscapes. The model is a fixed-effect model because the urban landscapes studied were not randomly chosen from a larger pool of urban landscapes. Consequently, these results are applicable to these specific types of urban environments. The urban landscapes studied are what we believe to be the most common urban environments; thus, our results are applicable to most of the urban environments an arborist would encounter. Repeated-measures analysis of variance and the general linear model procedure were used with Fisher's protected least-significant difference to detect seasonal changes and significant differences $(P \leq 0.05)$ among the urban land- 
scapes (SAS Institute, Inc., Cary, NC). Linear regression analyses were performed to investigate soil measurements significantly correlated $(P \leq 0.05)$ with soil nitrogen availability indices throughout the growing season across all sampled urban landscapes (SAS Institute, Inc.).

\section{RESULTS AND DISCUSSION}

Soil mineral nitrogen and dissolved organic nitrogen were not significantly different among the urban landscapes (Table 2). Mineral and dissolved organic nitrogen were found to vary erratically throughout the growing season on these urban landscapes, so much so that the time effect (time and time by treatment interaction $P \leq 0.0001$ ) confounded the differences among the environments. This is not surprising as these nitrogen pools turnover quickly and repeatedly within the growing season (Khan et al. 2001; Mulvaney and Khan 2001). One-time sampling of mineral and dissolved organic nitrogen revealed minimal insight into the spatial variability of nitrogen availability of these urban landscapes. Consequently, we do not suggest assessing the nitrogen availability of an urban landscape with a one-time sampling of extractable mineral or dissolved organic nitrogen.

The interactions of time and treatments for microbial biomass and activity were orderly. Although the time and time by treatment interaction were significant $(P \leq 0.0001)$, the spatial differences were temporally consistent (Scharenbroch et al. 2005); thus, for these parameters, we present and discuss spatial differences among these urban landscapes (Table 2). Microbial biomass nitrogen was found to be significantly greater $(67 \%$ to $79 \%)$ on old residential and park landscapes compared with old and new mulch and new residential landscapes. Street tree landscapes also had significantly greater (57\% to $70 \%$ ) microbial biomass nitrogen than mulched and new residential sites, but less (16\% to $34 \%$ ) than park and new residential sites. Carbon mineralization was found to be greater (30\% to 59\%) on new mulch compared with old mulch sites. Carbon mineralization also tended to be greater (15\% to $29 \%$ ) on park, old residential, and street landscapes compared with new residential landscapes. Likewise nitrogen mineralization was significantly greater $(62 \%$ to $97 \%)$ on park, old residential, and street landscapes compared with new residential landscapes. Nitrogen immobilization, detected by negative values of nitrogen mineralization, was found to occur only on new residential (9 of 16 sample dates), new mulch (4 of 16 sample dates), and old mulch (1 of 16 sample dates) landscapes.

The time effects on the SOM fractions were not significant in 2002 ( $P>0.14$ for $1 \mathrm{SOM}$, cPOM, and $\mathrm{PPOM})$ and significant but weak in 2003 ( $P \leq 0.03$ for all fractions). The interactions of time and treatments for the organic matter fractions were orderly (Scharenbroch et al. 2005), and spatial differences in organic matter fractions were significant among the urban landscapes (Table 3). Total SOM was significantly greater (23\% to $46 \%$ ) in old residential and park sites compared with new residential and old mulch sites. Mineral-associated SOM on old residential and park sites was significantly greater (23\% to $51 \%$ ) compared with new residential landscapes. Mineral-associated SOM on street sites was also significantly greater (5\% to $41 \%$ ) than new residential sites. Fine POM was significantly greater (41\% to $54 \%)$ on old residential and park compared with new residential and mulched sites. Fine POM from street tree landscapes was also significantly greater (30\% to $40 \%$ ) than from old mulched and new residential, but less than from old residential and park landscapes. Fine POM from new mulch landscapes was greater than from old mulch and new residential,

Table 2. Soil nitrogen pools from urban soils in Moscow, Idaho, and Pullman, Washington, in 2002 and 2003.

\begin{tabular}{|c|c|c|c|c|c|c|}
\hline Year & Landscape type & $\begin{array}{l}\text { MIN } \\
\left(\mu g \mathrm{Ng}^{-1}\right)\end{array}$ & $\begin{array}{l}\text { DON } \\
\left(\mu \mathrm{g} \mathrm{N} \mathrm{g}^{-1}\right)\end{array}$ & $\begin{array}{l}\mathrm{MBN} \\
\left(\mu \mathrm{g} \mathrm{N} g^{-1}\right)\end{array}$ & $\begin{array}{l}\text { PMC } \\
\left(\mu \mathrm{g} \mathrm{C} \mathrm{d}^{-1}\right)\end{array}$ & $\begin{array}{l}\text { PMN } \\
\left(\mu \mathrm{g} \mathrm{N} \mathrm{d}^{-1}\right)\end{array}$ \\
\hline \multirow[t]{6}{*}{2002} & New mulch & $10.3 \mathrm{a}$ & $3.0 \mathrm{a}$ & $14.1 \mathrm{c}$ & $23.6 \mathrm{a}$ & $0.38 \mathrm{~cd}$ \\
\hline & New residential & $8.0 \mathrm{a}$ & $1.2 \mathrm{ab}$ & $14.0 \mathrm{c}$ & $14.8 \mathrm{bc}$ & $0.13 \mathrm{~d}$ \\
\hline & Old mulch & $5.2 \mathrm{a}$ & $1.3 \mathrm{ab}$ & $16.9 \mathrm{c}$ & $12.5 \mathrm{c}$ & $0.50 \mathrm{bc}$ \\
\hline & Old residential & $5.9 \mathrm{a}$ & $1.9 \mathrm{ab}$ & $51.1 \mathrm{a}$ & $19.6 \mathrm{ab}$ & $0.60 \mathrm{bc}$ \\
\hline & Park & $9.4 \mathrm{a}$ & $2.3 \mathrm{ab}$ & $52.2 \mathrm{a}$ & $20.7 \mathrm{a}$ & $1.01 \mathrm{a}$ \\
\hline & Street tree & $10.0 \mathrm{a}$ & $0.8 \mathrm{~b}$ & $39.7 \mathrm{~b}$ & $19.1 \mathrm{ab}$ & $0.71 \mathrm{~b}$ \\
\hline \multirow[t]{6}{*}{2003} & New mulch & $6.0 \mathrm{a}$ & $1.7 \mathrm{a}$ & $10.2 \mathrm{c}$ & $17.8 \mathrm{a}$ & $0.15 \mathrm{~cd}$ \\
\hline & New residential & $4.4 \mathrm{a}$ & $2.0 \mathrm{a}$ & $16.5 \mathrm{c}$ & $15.2 \mathrm{ab}$ & $0.03 \mathrm{~d}$ \\
\hline & Old mulch & $4.6 \mathrm{a}$ & $2.1 \mathrm{a}$ & $13.0 \mathrm{c}$ & $9.9 \mathrm{~b}$ & $0.18 \mathrm{~cd}$ \\
\hline & Old residential & $5.8 \mathrm{a}$ & $2.3 \mathrm{a}$ & $54.0 \mathrm{ab}$ & $17.9 \mathrm{a}$ & $0.34 \mathrm{bc}$ \\
\hline & Park & $7.8 \mathrm{a}$ & $2.1 \mathrm{a}$ & $60.5 \mathrm{a}$ & $18.0 \mathrm{a}$ & $0.67 \mathrm{a}$ \\
\hline & Street tree & $7.5 \mathrm{a}$ & $1.8 \mathrm{a}$ & $42.9 \mathrm{~b}$ & $19.7 \mathrm{a}$ & $0.56 \mathrm{ab}$ \\
\hline
\end{tabular}

Means with same letter are not significantly different at $P \leq 0.05$.

Each value is the mean of nine or seven sample dates (2002 and 2003, respectively), with four plots per type, two subplots per plot, for a total of 72 (2002) and 56 (2003).

MIN, mineral N; DON, dissolved organic N; MBN, microbial biomass N; PMC, potentially mineralizable C; PMN, potentially mineralizable N. 
Table 3. Soil organic matter pools from urban soils in Moscow, Idaho, and Pullman, Washington, in 2002 and 2003.

\begin{tabular}{|c|c|c|c|c|c|c|c|c|}
\hline Year & Landscape type & $\begin{array}{l}\mathrm{tSOM} \\
\mathrm{kg} \mathrm{m}^{-2}\end{array}$ & $\begin{array}{l}\text { maSOM } \\
\mathrm{kg} \mathrm{m}^{-2}\end{array}$ & $\begin{array}{l}\text { fPOM } \\
\mathrm{kg} \mathrm{m}^{-2}\end{array}$ & $\begin{array}{l}\mathrm{cPOM} \\
\mathrm{kg} \mathrm{m}^{-2}\end{array}$ & $\begin{array}{l}\text { 1SOM } \\
\mathrm{kg} \mathrm{m}^{-2}\end{array}$ & $\begin{array}{l}\text { fPOM } \\
\mathrm{C} / \mathrm{N}\end{array}$ & $\begin{array}{l}\mathrm{cPOM} \\
\mathrm{C} / \mathrm{N}\end{array}$ \\
\hline \multirow[t]{4}{*}{2002} & New mulch & $12.423 \mathrm{ab}$ & $7.458 \mathrm{~b}$ & $1.379 \mathrm{bc}$ & $2.606 \mathrm{a}$ & $0.980 \mathrm{a}$ & $15.5 \mathrm{a}$ & $27.7 \mathrm{a}$ \\
\hline & Old mulch & $10.448 \mathrm{bc}$ & $8.229 \mathrm{a}$ & $0.980 \mathrm{c}$ & $0.853 \mathrm{~b}$ & $0.386 \mathrm{~b}$ & $20.5 \mathrm{a}$ & $34.5 \mathrm{a}$ \\
\hline & Old residential & $13.739 \mathrm{a}$ & $10.259 \mathrm{a}$ & $2.033 \mathrm{a}$ & $1.053 \mathrm{~b}$ & $0.394 \mathrm{~b}$ & $16.3 \mathrm{a}$ & $25.1 \mathrm{a}$ \\
\hline & Park & $14.307 \mathrm{a}$ & $10.955 \mathrm{a}$ & $1.978 \mathrm{a}$ & $0.985 \mathrm{~b}$ & $0.389 \mathrm{~b}$ & $15.7 \mathrm{a}$ & $26.1 \mathrm{a}$ \\
\hline & New residential & $10.599 \mathrm{c}$ & $7.927 \mathrm{~b}$ & $1.047 \mathrm{c}$ & $1.197 \mathrm{~b}$ & $0.428 \mathrm{~b}$ & $19.8 \mathrm{a}$ & $30.5 \mathrm{a}$ \\
\hline & Old mulch & $11.787 \mathrm{bc}$ & $9.501 \mathrm{a}$ & $1.018 \mathrm{c}$ & $0.886 \mathrm{~b}$ & $0.382 \mathrm{~b}$ & $20.4 \mathrm{a}$ & $35.0 \mathrm{a}$ \\
\hline & Old residential & $15.740 \mathrm{a}$ & $12.301 \mathrm{a}$ & $1.900 \mathrm{a}$ & $1.073 \mathrm{~b}$ & $0.466 \mathrm{~b}$ & $16.6 \mathrm{a}$ & $25.2 \mathrm{a}$ \\
\hline & Park & $15.942 \mathrm{a}$ & $12.828 \mathrm{a}$ & $1.777 \mathrm{a}$ & $0.913 b$ & $0.424 \mathrm{~b}$ & $16.1 \mathrm{a}$ & $25.7 \mathrm{a}$ \\
\hline & Street tree & $13.830 \mathrm{ab}$ & $10.608 \mathrm{a}$ & $1.492 \mathrm{ab}$ & $1.173 \mathrm{~b}$ & $0.557 \mathrm{ab}$ & $20.5 \mathrm{a}$ & $28.9 \mathrm{a}$ \\
\hline
\end{tabular}

Means with same letter are not significantly different at $P \leq 0.05$.

Each value is the mean of nine or seven sample dates (2002 and 2003, respectively), with four plots per type, two subplots per plot, for a total of 72 (2002) and 56 (2003).

tSOM, total soil organic matter; maSOM, mineral-associated soil organic matter; fPOM, fine particulate organic matter; cPOM, coarse particulate organic matter; 1SOM, and litter soil organic matter.

but less than street, old residential, and park landscapes. Litter SOM and coarse POM were significantly greater (34\% to $66 \%$ and $41 \%$ to $68 \%$, respectively) in new mulch compared with all urban landscapes except street sites, where litter SOM on street and new sites were not significantly different.

To emphasize spatial differences of soil nitrogen, we focus on a comparison between new and old residential soils (Figure 1). New and old residential landscapes had many soilforming factors in common (i.e., climate, biota, relief, and parent material) (Jenny 1941). We suspect that the soil-

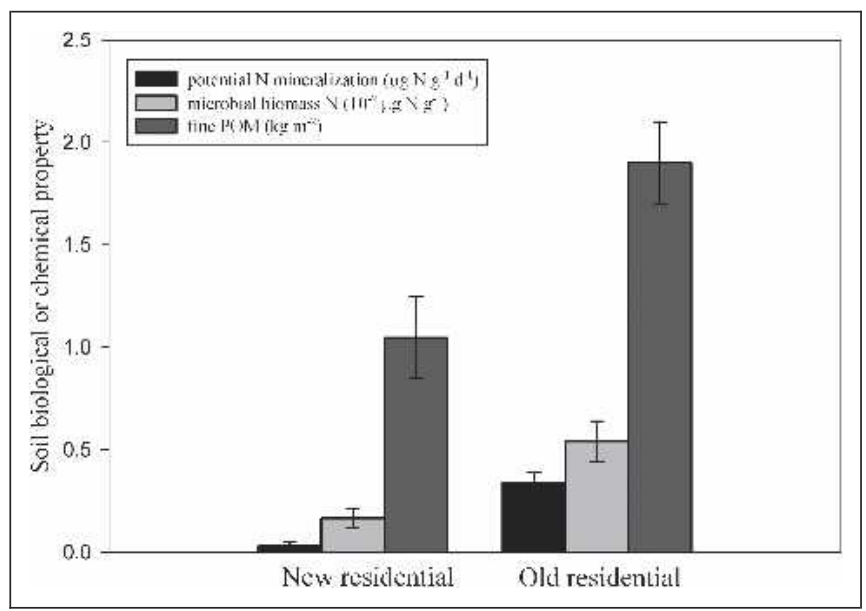

Figure 1. A comparison of microbial biomass $\mathrm{N}$, potentially mineralizable $\mathrm{N}$, and fine particulate organic matter from old and new residential landscape soils of Moscow, Idaho, and Pullman, Washington, in 2003. Each value is the mean of seven sample dates, with four plots per type, two subplots per plot, for a total of 56 . forming factor these landscapes differed mostly in was time since initial site disturbance. It is reasonable to assume that if spatial variability in soil nitrogen is evident when only time is different, additional variation can be expected when other soil-forming factors also vary among urban landscapes.

Biologic measurements of nitrogen availability were significantly greater in old compared with new residential soils, MBN (71\%) and PMN (83\%). Potential carbon mineralization was greater $(20 \%)$ in old compared with new residential soils. Negative values of PMN, indicating nitrogen immobilization, were measured in soils from new residential landscapes on 9 of 16 sample dates, but not measured in soils from old residential landscapes. Nitrogen is more limited and tends to be immobilized when substrate $\mathrm{C} / \mathrm{N}$ exceeds approximately 25/1 (Brady and Weil 2002). The C/N ratios of the $\mathrm{POM}$ fractions from old residential landscapes (fine POM of 16.5 and coarse POM of 25.2) were less than on new residential landscapes (fine POM of 18.9 and coarse POM of 29.3), likely contributing to the preference of nitrogen mineralization over immobilization on old residential sites. Fine POM was significantly greater $(50 \%)$ on old compared with new residential soils. The proportionate contribution to the total SOM of the fine POM fraction increased and the coarse POM fractions decreased in the older urban landscapes. Furthermore, the $\mathrm{C} / \mathrm{N}$ ratios of the coarse POM fractions (mean of 28.4) were greater than the fine POM fractions (mean of 18.0). Because carbon is mineralized through microbial respiration and nitrogen is conserved through microbial immobilization, the $\mathrm{C} / \mathrm{N}$ ratio of the organic material will decrease with decomposition. Increases in finer-particle SOM and decreases in the $\mathrm{C} / \mathrm{N}$ ratio are indicative of soil organic stabilization and humification (Quideau and Bockheim 1996). 


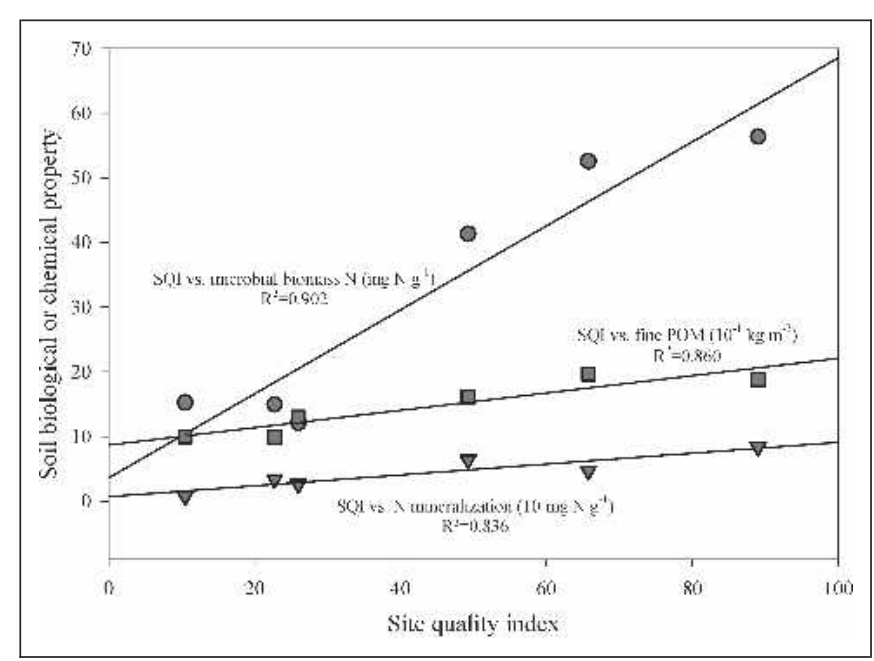

Figure 2. $\mathrm{R}^{2}$ correlations for fine particulate organic matter, microbial biomass $\mathbf{N}$, and $\mathbf{N}$ mineralization with site quality index in urban soils of Moscow, Idaho, and Pullman, Washington, in 2003. Each value is the mean of 16 sample dates, with four plots per type, two subplots per plot, for a total of 128 .

We found our site quality index to be significantly and positively correlated with fine POM, microbial biomass $\mathrm{N}$, and $\mathrm{N}$ mineralization $\left(\mathrm{R}^{2}\right.$ values of $0.86,0.90$, and 0.84 , respectively) (Figure 2). Our site quality index incorporated management practices, but was mostly affected by landscape age. We suspect the differences of soil nitrogen pools among these urban landscapes are primarily derived from variances in time since initial site disturbances (Scharenbroch et al. 2005). Old residential, street, and park landscapes are older urban landscapes with mature trees (mean of 64 years old) and longer times since initial site disturbance; conversely, new residential, old mulch, and new mulch sites are younger urban landscapes (mean of 9 years old). As urban soils develop after initial site disturbances soil bulk densities decrease, clay contents in the upper mineral horizons decrease as clay particles migrate lower in the soil profile, fine to coarse $\mathrm{POM}$ ratios increase, the $\mathrm{C} / \mathrm{N}$ ratios of soil organic matter become narrower, and the microbial activity and biomass of soils increase (Scharenbroch et al. 2005). We suspect that these pedologic processes have led to differences in nitrogen availability in these urban landscapes.
Current nitrogen fertilization standards, 1000 to $2000 \mathrm{~kg} \mathrm{~N}$ $\mathrm{ha}^{-1} \mathrm{yr}^{-1}$ (2 to $4 \mathrm{lb}$ of $\mathrm{N} 1000 \mathrm{ft}^{-2} \mathrm{yr}^{-1}$ ), are not site-specific (ANSI A300 2001). However, our results show that soil nitrogen is significantly different among urban landscapes. Nitrogen mineralization over a 200-day growing season on old residential sites accounts for approximately 1500 to $3,000 \mathrm{~kg}$ $\mathrm{N}$ ha $^{-1} \mathrm{yr}^{-1}$ (3 to $6 \mathrm{lb}$ of $\mathrm{N} 1000 \mathrm{ft}^{-2} \mathrm{yr}^{-1}$ ) and on new residential sites only $150 \mathrm{~kg} \mathrm{~N} \mathrm{ha}^{-1} \mathrm{yr}^{-1}\left(0.3 \mathrm{lb}\right.$ of N $1000 \mathrm{ft}^{-2}$ $\left.\mathrm{yr}^{-1}\right)$. Therefore, the nitrogen supply on old residential landscapes may be as much as 10 to 20 times that of new residential landscapes. Using blanket recommendations across these sites could result in overapplication of nitrogen on old residential sites and possible underapplication on new residential sites. These results stress the importance of considering the spatial variability of microbial indices in urban soils when making nitrogen management recommendations. Although microbial biomass and activity did not vary so much that the spatial differences were hidden like mineral and dissolved organic nitrogen, these measures did change throughout the growing season. Consequently, urban landscape managers would have to consider temporal changes in these microbial indices to use them to assess nitrogen availability. Ideally, urban landscape managers would be able to assess nitrogen availability over one or two growing seasons with a one-time sampling. To address this goal, we examined correlations of relatively stable soil organic matter pools with microbial biomass and activity.

According to data from Buyanovsky et al. (1994), coarse POM turnover is estimated to be less than 1 year and mineral associated SOM turnover to be greater than 400 years (Table 4). Consequently, coarse POM turnover is too quick to be used to assess seasonal nitrogen availability. Because maSOM includes recalcitrant organic matter held on clay and silt particles or within clay lattices, it turns over too slowly to be used to assess seasonal nitrogen availability. Fine POM turnover times are estimated to be 1 to 2 years and thus would be ideal to relate seasonal nitrogen availability.

Linear regressions were performed for all SOM fractions with potential $\mathrm{N}$ mineralization and microbial biomass $\mathrm{N}$ on each sample date. Of the soil organic pools, fine POM measurements most consistently correlated with MBN and PMN throughout both growing seasons. The quantity of fine POM determined by the LOI method consistently and accurately

Table 4. Physical soil organic matter fractions and their respective turnover times.

\begin{tabular}{lll}
\hline SOM fraction from this study & Organic component* & Turnover time* \\
\hline Coarse POM 2.0 to $0.25 \mathrm{~mm}$ & Vegetable fragments 2.0 to $0.2 \mathrm{~mm}$ & 0.5 to $1 \mathrm{yr}$ \\
Fine POM 0.25 to $0.053 \mathrm{~mm}$ & Vegetable fragments 0.2 to $0.053 \mathrm{~mm}$ & 1 to $2 \mathrm{yr}$ \\
Mineral-associated SOM $<0.053 \mathrm{~mm}$ & Silt associated 0.053 to 0.002 & Approximately $400 \mathrm{yr}$ \\
& Fine clay associated $<0.002 \mathrm{~mm}$ & Approximately 1000 yr
\end{tabular}

*Data from Buyanovsky et al. 1994.

SOM, soil organic matter; POM, particulate organic matter. 
Table 5. $\mathbf{R}^{2}$ correlations for fine POM and potential $\mathrm{N}$ mineralization and microbial biomass $\mathrm{N}$ throughout two growing seasons in urban soils in Moscow, Idaho, and Pullman, Washington, in 2002 and 2003.

\begin{tabular}{lll}
\hline & $\begin{array}{l}\text { Potential N } \\
\text { mineralization }\end{array}$ & $\begin{array}{l}\text { Microbial } \\
\text { biomass N }\end{array}$ \\
\cline { 2 - 3 } & Fine POM kg m & \\
\cline { 3 - 3 } $5 / 17 / 02$ & 0.371 & Fine POM kg m \\
$5 / 01 / 02$ & 0.325 & 0.693 \\
$5 / 15 / 02$ & 0.706 & 0.958 \\
$5 / 29 / 02$ & $0.037 *$ & 0.531 \\
$6 / 12 / 02$ & 0.168 & 0.940 \\
$6 / 26 / 02$ & 0.266 & 0.745 \\
$8 / 07 / 02$ & 0.737 & 0.595 \\
$9 / 05 / 02$ & 0.524 & 0.400 \\
$10 / 03 / 02$ & 0.342 & 0.740 \\
$4 / 11 / 03$ & 0.537 & 0.966 \\
$5 / 09 / 03$ & 0.386 & 0.309 \\
$6 / 13 / 03$ & 0.222 & 0.795 \\
$7 / 11 / 03$ & 0.628 & 0.651 \\
$8 / 08 / 03$ & 0.640 & 0.760 \\
$9 / 13 / 03$ & 0.437 & 0.888 \\
$10 / 10 / 03$ & 0.575 & 0.919 \\
Mean & 0.431 & 0.802 \\
\hline
\end{tabular}

*Not significant at the $P \leq 0.05$.

$\mathrm{POM}$, particulate organic matter.

explained variance in microbial biomass $\mathrm{N}$ (mean $\mathrm{R}^{2}=0.73$ and 16 of 16 significant) and potential $\mathrm{N}$ mineralization (mean $\mathrm{R}^{2}=0.43$ and 15 of 16 significant) (Table 5). In addition, both the carbon and nitrogen contents of the fine POM determined by automated dry combustion were significantly correlated with MBN and PMN on all dates (Table 6). Seasonal mean values for microbial biomass, carbon mineralization, and nitrogen mineralization were significantly correlated with fine POM (Table 7). Fine POM explained much of the variance in seasonal mean microbial biomass nitrogen $\left(\mathrm{R}^{2}\right.$ values of 0.758 and 0.886$)$ and nitrogen mineralization
Table 6. $\mathrm{R}^{2}$ correlations for fine POM $\mathrm{C}$ and $\mathrm{N}$ contents and potential $\mathrm{N}$ mineralization and microbial biomass $\mathrm{N}$ throughout two growing seasons in urban soils in Moscow, Idaho, and Pullman, Washington, in 2002 and 2003.

\begin{tabular}{|c|c|c|c|c|}
\hline \multirow[b]{2}{*}{ Date } & \multicolumn{2}{|c|}{ Potential $\mathrm{N}$ mineralization } & \multicolumn{2}{|c|}{ Microbial biomass $\mathrm{N}$} \\
\hline & $\begin{array}{l}\text { Fine } \\
\text { POM N }\end{array}$ & $\begin{array}{l}\text { Fine } \\
\text { POM C }\end{array}$ & $\begin{array}{l}\text { Fine } \\
\text { POM N }\end{array}$ & $\begin{array}{l}\text { Fine } \\
\text { POM C }\end{array}$ \\
\hline $4 / 17 / 02$ & 0.496 & 0.477 & 0.565 & 0.654 \\
\hline $5 / 15 / 02$ & 0.638 & 0.640 & 0.509 & 0.643 \\
\hline $6 / 12 / 02$ & 0.299 & 0.221 & 0.743 & 0.781 \\
\hline $8 / 07 / 02$ & 0.670 & 0.803 & 0.195 & 0.319 \\
\hline $10 / 03 / 02$ & 0.179 & 0.343 & 0.854 & 0.956 \\
\hline $4 / 11 / 03$ & 0.440 & 0.483 & 0.181 & 0.301 \\
\hline $6 / 13 / 03$ & 0.183 & 0.274 & 0.486 & 0.667 \\
\hline 8/08/03 & 0.490 & 0.614 & 0.637 & 0.811 \\
\hline $10 / 10 / 03$ & 0.680 & 0.706 & 0.540 & 0.532 \\
\hline Mean & 0.453 & 0.507 & 0.523 & 0.629 \\
\hline
\end{tabular}

POM, particulate organic matter.

$\left(\mathrm{R}^{2}\right.$ values of 0.614 and 0.558$)$. Fine POM best related differences among the urban landscapes that corresponded to differences detected in microbial biomass, carbon mineralization, and nitrogen mineralization. Like the soil biologic measurements, fine POM was greater on old residential, park, and street sites compared with new residential and mulch sites.

Particulate organic matter may be a practical and accurate nitrogen assessment tool, but measurements are yet to be related to plant productivity and specific nitrogen fertilization recommendations. Our data show that fine POM corresponds to a rate of soil nitrogen mineralization, which could be used to calculate the potential amount of available nitrogen over a growing season. Before prescription fertilization can adopt a POM measurement, more data need to be collected from a wider range of urban soils relating POM with available soil nitrogen, fertilization, and plant performance.

Table 7. $\mathrm{R}^{2}$ correlations among fine POM and microbial measures in urban soils in Moscow, Idaho, and Pullman, Washington, in 2002 and 2003.

\begin{tabular}{llllll}
\hline Year & Measure & $\begin{array}{l}\text { Fine } \\
\text { POM }\end{array}$ & $\begin{array}{l}\text { Microbial } \\
\text { biomass N }\end{array}$ & $\begin{array}{l}\text { Potential C } \\
\text { mineralization }\end{array}$ & $\begin{array}{l}\text { Potential N } \\
\text { mineralization }\end{array}$ \\
\hline 2002 & Fine POM & 1.000 & - & - & - \\
& Microbial biomass N & 0.758 & 1.000 & - & - \\
& Potential C mineralization & 0.422 & 0.132 & 1.000 & - \\
& Potential N mineralization & 0.614 & 0.686 & 0.126 & - \\
& Fine POM & 1.000 & - & - & - \\
& Microbial biomass N & 0.886 & 1.000 & - & - \\
& Potential C mineralization & 0.431 & 0.335 & 0.000 & 1.000 \\
& Potential N mineralization & 0.558 & 0.733 & 0.300 & \\
\end{tabular}

All correlations significant at $P \leq 0.05$.

Each value is the mean of 9 or 7 sample dates (2002 and 2003, respectively), with four plots per type, two subplots per plot, for a total of 72 (2002) and 56 (2003). POM, particulate organic matter. 


\section{CONCLUSION}

Investigations of soil nitrogen, microbes, and organic matter quantity and quality reveal information of the dynamic processes that determine nitrogen availability in these soils. Prescribing a fertilization treatment without investigating the soil nitrogen status is currently acceptable (ANSI A300 2001) and common because of limited nitrogen assessment technology. We have shown that spatial variability in soil nitrogen exists among these urban landscapes, and it is important to account for this when making nitrogen management decisions. Of the nitrogen diagnostic techniques examined, fine POM measurements had the greatest potential to serve as practical methods of accurately estimating soil nitrogen availability in these urban landscapes. Once POM measures are tested with fertilization and plant performance, they could serve as relatively easy and beneficial incorporations to plant health care programs and would help to emphasize the roles urban landscape managers have as stewards of urban environments.

Acknowledgments. We thank Richard Gill, Ph.D., Jodi Johnson-Maynard, Ph.D., Donald Thill, Ph.D., Robert Tripepi, Ph.D., and the anonymous reviewers for their suggestions. We also thank the TREE Fund (John Duling Grant) and

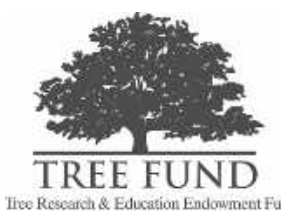

the University of Idaho Seed Grant for their support of this project. This article is dedicated to the memory of Benjamin R. Stinner.

\section{LITERATURE CITED}

Alvarez, C.R., R. Alvarez, M.S. Grigera, and R.S. Lavado. 1998. Associations between organic matter fractions and the active soil microbial biomass. Soil Biology \& Biochemistry 30:767-773.

Anderson, J.P.E., and K.H. Domsch. 1978. A physiological method for the quantitative measurement of microbial biomass in soils. Soil Biology \& Biochemistry 10: 215-221.

Anderson, P., D. Berggren, and I. Nilsson. 2002. Indices for nitrogen status and nitrate leaching from Norway spruce (Picea abies L. Karst.) stands in Sweden. Forest Ecology and Management 157:39-53.

Bayer, C., L. Martin-Neto, J. Mielniczuk, C.N. Pillon, and L. Sangoi. 2001. Changes in soil organic matter fractions under subtropical no-till cropping systems. Soil Science Society of America Journal 65:1473-1478.

Beverly, R.B., W. Florkowski, and J.M. Ruter. 1997. Fertilizer management by landscape maintenance and lawn care firms in Atlanta. HortTechnology 7:442-445.

Beyer, L., E. Cordsen, H.-P. Blume, U. Schleuss, B. Vogt, and Q. Wu. 1996. Soil organic matter composition in urbic anthrosols in the city of Kiel, NW-Germany, as revealed by wet chemistry and CPMAS 13C-NMR spectroscopy of whole soil samples. Soil Technology 9: 121-132.
Beyer, L., H.-P. Blume, D.-C. Elsner, and A. Willnow. 1995. Soil organic matter composition and microbial activity in urban soils. The Science of the Total Environment 168: 267-278.

Biederbeck, V.O., H.H. Janzen, C.A. Campbell, and R.P. Zenter. 1994. Labile organic matter as influenced by cropping practices in an arid environment. Soil Biology \& Biochemistry 12:1647-1656.

Brady, N.C., and R.R. Weil. 2002. The Nature and Properties of Soils. 13th Ed. Prentice Hall, Englewood Cliffs, NJ.

Brookes, P.C., A. Landman, G. Pruden, and D.S. Jenkinson. 1985. Chloroform fumigation and the release of soil nitrogen: A rapid direct extraction method to measure microbial biomass nitrogen in soil. Soil Biology \& Biochemistry $17: 837-842$.

Burger, J.A., and W.L. Pritchett. 1984. Effects of clearfelling and site preparation on nitrogen mineralization in a southern pine stand. Soil Science Society of America Journal 48:1432-1437.

Buyanovsky, G.A., M. Aslam, and G.H. Wagner. 1994. Carbon turnover in soil physical fractions. Soil Science Society of America Journal 58:1167-1173.

Cabrera, M.L., and M.H. Beare. 1993. Alkaline persulfate oxidation for determining total nitrogen in microbial biomass estimates. Soil Science Society of America Journal 57:1007-1012.

Cambardella, C.A., and E.T. Elliott. 1992. Particulate soil organic matter changes across a grassland cultivation sequence. Soil Science Society of America Journal 56: 777-783.

- 1993. Carbon and nitrogen distribution in aggregates from cultivated and native grassland soils. Soil Science Society of America Journal 57:1071-1076.

Campbell, C.A. 1978. Soil organic carbon, nitrogen, and fertility, pp. 173-272. In Schnitzer, M., and S.U. Khan (Eds.). Soil Organic Matter. Elsevier Scientific, Amsterdam, The Netherlands.

Carreiro, M.M., K. Howe, D.F. Parkhurst, and R.V. Pouyat. 1999. Variation in quality and decomposibility of red oak leaf litter along an urban-rural gradient. Biology and Fertility of Soils 30:258-268.

Chan, K.Y. 1997. Consequences of changes in particulate organic carbon in vertisols under pasture and cropping. Soil Science Society of America Journal 61:1382-1386.

Chefetz, B., J. Tarchitzky, A.P. Deshmukh, P.G. Hatcher, and Y. Chen. 2002. Structural characterization of soil organic matter and humic acids in particle-size fractions of an agricultural soil. Soil Science Society of America Journal 66:12-141.

Ding, G., J.M. Novak, D. Amarasiriwardena, P.G. Hunt, and B. Xing. 2002. Soil organic matter characteristics as affected by tillage management. Soil Science Society of America Journal 66:421-429. 
Doran, J.W., and A.J. Jones. 1996. Methods for Assessing Soil Quality. Soil Science Society of America, Madison, WI.

Drinkwater, L.E., C.A. Cambardella, J. Reeder, and C.W. Rice. 1996. Potentially mineralizable nitrogen as an indicator of biologically active soil nitrogen, pp. 217-229. In Doran, J.W., and A.J. Jones (Eds.). Methods for Assessing Soil Quality. Soil Science Society of America, Madison, WI.

Duriancik, L.F. 2001. Seasonal Carbon and Nitrogen Cycling in a Corn to Pasture Chronosequence and Implications for Soil Carbon and Nitrogen Storage Over Time. Thesis, The Ohio State University, Columbus, OH.

Elliot, E.T., and C.A. Cambardella. 1991. Physical separation of soil organic matter. Agriculture Ecosystems \& Environment 34:407-419.

Evangelou, V.P. 1998. Environmental Soil and Water Chemistry Principles and Applications. Wiley and Sons, New York, NY.

Fox, T.R., J.A. Burger, and R.H. Kreh. 1986. Effects of site preparation on nitrogen dynamics in the southern Piedmont. Forest Ecology and Management 15:241-256.

Franzlubbers, A.J., and J.A. Stuedemann. 2003. Bermudagrass management in the southern piedmont USA. III. Particulate and biologically active soil carbon. Soil Science Society of America Journal 67:132-138.

Gardner, W.H. 1965. Water content. In C.A. Black, et al. (Eds.). Methods of Soil Analysis. Part 1. Physical and Mineralogical Properties, Including Statistics of Measurement and Sampling. Agronomic Monograph 9. American Society of Agronomy and Soil Science Society of America, Madison, WI.

Gill, R., I.C. Burke, D.G. Milchunas, and W.K. Lauenroth. 1999. Relationship between root biomass and soil organic matter pools in the shortgrass steppe of eastern Colorado. Ecosystems, New York 2:226-236.

Goldman, M.B., P.M. Groffman, R.V. Pouyat, M.J. McDonnell, and T.A. Pickett. 1995. $\mathrm{CH}_{4}$ uptake and $\mathrm{N}$ availability in forest soils along an urban to rural gradient. Soil Biology \& Biochemistry 27:281-286.

Graham, M.H., R.J. Haynes, and J.H. Meyer. 2002. Soil organic matter content and quality: Effects of fertilizer applications, burning and trash retention on a long-term sugarcane experiment in South Africa. Soil Biology \& Biochemistry 34:93-102.

Gregorich, E.G., M.R. Carter, D.A. Anger, C.M. Monreal, and B.H. Ellert. 1994. Towards a minimum data set to assess soil organic matter quality in agricultural soils. Canadian Journal of Soil Science 74:367-385.

Janzen, H.H., C.A. Campbell, R.C. Izaurralde, B.H. Ellert, N. Juma, W.B. McGill, and R.P. Zenter. 1998. Management effects on soil C storage on the Canadian prairies. Soil \& Tillage Research 47:181-195.
Janzen, H.H., C.A. Campbell, S.A. Brandt, G.P. Lafond, and L. Townley-Smith. 1992. Light-fraction organic matter in soils from long-term rotations. Soil Science Society of America Journal 56:1799-1806.

Jenny, H. 1941. Factors of Soil Formation: A System of Quantitative Pedology. Dover Publications, New York, NY.

Joergensen, R.G., and T. Mueller. 1996. The fumigationextraction method to estimate soil microbial biomass: Calibration of the kEN value. Soil Biology \& Biochemistry $28: 33-37$.

Kaiser, E.-A., T. Mueller, R.G. Joergensen, H. Insam, and O. Heinemeyer. 1992. Evaluation of methods to estimate the soil microbial biomass and the relationship with soil texture and organic matter. Soil Biology \& Biochemistry 27:675-683.

Keeney, D.R. 1982. Nitrogen availability indices. In A.L. Page (Ed.). Methods of Soil Analysis. Part 2. 2nd Ed. Agronomic Monograph 9. American Society of Agronomy and Soil Science Society of America, Madison, WI.

Khan, S.A., R.L. Mulvaney, and R.G. Hoeft. 2001. A simple soil test for detecting sites that are nonresponsive to nitrogen fertilization. Soil Science Society of America Journal 65:1751-1760.

Knoepp, J.D., D.C. Coleman, D.A. Crossley Jr., and J.S. Clark. 2000. Biological indices of soil quality: An ecosystem case study of their use. Forest Ecology and Management 138:357-368.

Kopinga, J., and J. van den Burg. 1995. Using soil and foliar analysis to diagnose the nutritional status of urban trees. Journal of Arboriculture 21:17-23.

Magid, J., A. Gorissen, and K.E. Giller. 1996. In search of the elusive 'active' fraction of soil organic matter: Three sizedensity fractionation methods for tracing the fate of homogeneously ${ }^{14} \mathrm{C}$-labelled plant materials. Soil Biology \& Biochemistry 28:89-99.

McLaughlin, J.W., M.R. Gale, M.F. Jurgensen, and C.C. Trettin. 2000. Soil organic matter and nitrogen cycling in response to harvesting, mechanical site preparation, and fertilization in a wetland with a mineral substrate. Forest Ecology and Management 129:7-23.

Molina, J.A.E., C.E. Clapp, M.J. Schafer, F.W. Chichester, and W.E. Larson. 1983. NCSOIL, a model of nitrogen and carbon transformations in soil: description, calibration, and behavior. Soil Science Society of America Journal 47:85-91.

Mulvaney, R.L., and S.A. Khan. 2001. Diffusion methods to determine different forms of nitrogen in soil hydrolysates. Soil Science Society of America Journal 65:1284-1292.

Osmond, D.L., and J.L. Platt. 2000. Characterization of suburban nitrogen fertilizer and water use on residential turf in Cary, North Carolina. HortTechnology 10:320-325. 
Parkin, T.B., J.W. Doran, and E. Franco-Vizcaino. 1996. Field and laboratory tests of soil respiration, pp. 231-245. In Doran, J.W., and A.J. Jones. (Eds.). Methods for Assessing Soil Quality. Soil Science Society of America, Madision, WI.

Parton, W.J., D.S. Schimel, C.V. Cole, and D.S. Ojima. 1987. Analysis of factors controlling soil organic matter levels in great plains grasslands. Soil Science Society of America Journal 51:1173-1179.

Paul, E.A. 1984. Dynamics of organic matter in soils. Plant and Soil 76:275-285.

Patten, R. 2003. Idaho Climate Records, Moscow, ID. http:// snow.ag.uidaho.edu/climate/select_mos.htm (accessed $12 / 08 / 03)$.

Paustian, K., W.J. Parton, and J. Persson. 1992. Modeling soil organic matter in organic-amended and nitrogen-fertilized long-term plots. Soil Science Society of America Journal 56:476-488.

Picone, L.I., M.L. Cabrera, and A.J. Franzluebbers. 2002. A rapid method to estimate potentially mineralizable nitrogen in soil. Soil Science Society of America Journal 66: 1843-1847.

Pouyat, R., P. Groffman, I. Yesilonis, and L. Hernandez. 2002. Soil carbon pools and fluxes in urban ecosystems. Environmental Pollution (Barking, Essex: 1987) 116: 107-118.

Pouyat, R.V., M.J. McDonnell, and S.T.A. Pickett. 1995. Soil characteristics of oak stands along an urban-rural land-use gradient. Journal of Environmental Quality 24:516-526.

Powlson, D.S., P.C. Brookes, and B.T. Christensen. 1987. Measurement of soil microbial biomass provides an early indication of changes in total soil organic matter due to straw incorporation. Soil Biology \& Biochemistry 19: 159-164.

Qafoku, O.S., M.L. Cabrera, W.R. Windham, and N.S. Hill. 2001. Rapids methods to determine potentially mineralizable nitrogen in broiler litter. Journal of Environmental Quality 30:217-221.

Quideau, S.A., and J.G. Bockheim. 1996. Vegetation and cropping effects on pedogenic processes in a sandy prairie soil. Soil Science Society of America Journal 60:536-545.

Rice, C.W., T.B. Moorman, and M. Beare. 1996. Role of microbial biomass carbon and nitrogen in soil quality, pp. 203-215. In Doran, J.W., and A.J. Jones (Eds.). Methods for Assessing Soil Quality. Soil Science Society of America, Madision, WI.

Roberts, R.D., and J.M. Roberts. 1984. The selection and management of soils in landscape schemes, pp. 99-126. In Bradshaw, A.D., Goode, D.A., and E.H.P. Thorp (Eds.). Ecology and Design in the Landscape. Blackwell Scientific, Oxford, UK.

Ross, D.J. 1992. Influence of sieve mesh size on estimates of microbial carbon and nitrogen by fumigation-extraction procedures in soils under pasture. Soil Biology \& Biochemistry 24:343-350.

Salas, A.M., E.T. Elliot, D.G. Westfall, C.V. Cole, and J. Six. 2003. The role of particulate organic matter in phosphorous cycling. Soil Science Society of America Journal 67:181-189.

Scharenbroch, B.C., and J.E. Lloyd. 2004. A literature review of nitrogen availability indices for use in urban landscapes. Journal of Arboriculture 30:214-229.

Scharenbroch, B.C., J.E. Lloyd, and J.L. Johnson-Maynard. 2005. Distinguishing urban environments with physical, chemical, and biological soil properties. Pedobiologia 49: 283-296.

Schnitzer, M. 1986. Binding of humic substances by soil mineral colloids, pp. 77-101. In Huang, M., and M. Schnitzer (Eds.). Interactions of Soil Minerals with Natural Organics and Microbes. Special Publication No. 17. Soil Science Society of America, Madison, WI.

Schulte, E.E., C. Kaufman, and J.B. Peter. 1991. The influence of sample size and heating time on soil weight losson-ignition. Communications in Soil Science and Plant Analysis 22:159-166.

Sikora, L.J., and D.E. Stott. 1996. Soil organic carbon and nitrogen, pp. 157-167. In Doran, J.W., and A.J. Jones (Eds). Methods for Assessing Soil Quality. Soil Science Society of America, Inc., Madison, WI.

Sims, G.K., T.R. Ellsworth, and R.L. Mulvaney. 1995. Microscale determination of inorganic nitrogen in water and soil extracts. Communications in Soil Science and Plant Analysis 26:303-316.

Six, J., E.T. Elliot, K. Paustian, and J.W. Doran. 1998. Aggregation and soil organic matter accumulation in cultivated and native grassland soils. Soil Science Society of America Journal 62:1367-1377.

Six, J., P. Callewaert, S. Lenders, S. De Gryze, S.J. Morris, E.G. Gregorich, E.A. Paul, and K. Paustian. 2002. Measuring and understanding carbon storage in afforested soils by physical fractionation. Soil Science Society of America Journal 66:1981-1987.

Sohn Lopez-Forment, I. 2000. Ecological and Socio-Cultural Dynamics of Traditional and Legume Based MILPA Agriculture in Southeast Mexico. Dissertation, The Ohio State University, Columbus, $\mathrm{OH}$.

Smith, M.A.L., A.G. Endress, G.R. Smith, J.E. Lloyd, R.D. Neely, R.K. Stutman, J.J. Ball, and K.D. Coder. 2002. A Guide to the Plant Health Care Management System. 3rd ed. International Society of Arboriculture, Champaign, IL.

Sparling, G.P., C.W. Feltman, J. Reynolds, A.W. West, and P. Singleton. 1990. Estimation of soil microbial C by a fumigation-extraction method: Use on soils of high organic matter content, and a reassessment of the kEC factor. Soil Biology \& Biochemistry 22:301-307. 
Stanford, G., and S.J. Smith. 1972. Nitrogen mineralization potentials of soils. Soil Science Society of America Proceedings 36:465-472.

Stinner, B.R., D. McCartney, and E.R. Zaborski. 2002. Role of labile soil organic matter and soil microbial biomass in nitrogen cycling processes across a range of soil conditions and management history in northeastern Ohio. Proceedings of the International Symposium on Composting and Compost Utilization, Columbus, $\mathrm{OH}$.

Tisdale, J.M., and J.M. Oades. 1982. Organic matter and water-stable aggregates in soils. Journal of Soil Science 33:141-163.

Tree Care Industry Association (TCIA). 2001. American National Standard for Tree Care Operations-Tree, Shrub, and Other Woody Plant Maintenance-Standard Practices (Fertilization) (A300, Part 2). Tree Care Industry Association, Manchester, $\mathrm{NH}$.

United States Department of Agriculture (USDA). 1980. United States Department of Agriculture Soil Conservation Service Soil Surveys of Whitman County.

—_ 1981. United States Department of Agriculture Soil Conservation Service, Soil Surveys of Latah County.

Verchot, L.V., Z. Holmes, L. Mulon, P.M. Groffman, and G.M. Lovett. 2001. Gross vs net rates of $\mathrm{N}$ mineralization and nitrification as indicators of functional differences between forest types. Soil Biology \& Biochemistry 33: 1889-1901.

White, C.S., and M.J. McDonnell. 1988. Nitrogen cycling processes and soil characteristics in an urban versus rural forest. Biogeochemistry 5:243-262.

Zhu, W.-X., and M.M. Carreiro. 1999. Chemoautotrophic nitrification in acidic forest soils along an urbanto-rural transect. Soil Biology \& Biochemistry 31: 1091-1100.

Bryant C. Scharenbroch (corresponding author)

1525 Observatory Drive

Department of Soil Science

College of Agricultural and Life Sciences

University of Wisconsin-Madison

Madison, WI 53706-1299, U.S.

bcscharenbro@wisc.edu

John E. Lloyd

Department of Plant, Soil, and Entomological Sciences

College of Agriculture and Life Science

University of Idaho, P.O. Box 442339

Moscow, ID 83844-2339, U.S.

Résume. Afin de développer une gestion de l'azote dans l'entretien des arbres ornementaux, nous avons étudié la matière organique du sol, la biomasse microbienne ainsi que la minéralisa- tion du carbone et de l'azote pour tenter de caractériser la quantité disponible d'azote pour la plante au sein d'une variété de conditions de gestion en milieu aménagé. Les fractions de fines particules de matière organique étaient significativement corrélées avec la biomasse microbienne, la minéralisation du carbone et celle de l'azote (valeurs de $\mathrm{R}^{2}$ entre 0,42 et 0,89 ). Ces aménagements urbains ont reçu un index de qualité de site basé sur l'âge de l'aménagement et les pratiques de gestion. Les fines particules de matière organiques, la biomasse microbienne de l'azote et la minéralisation de l'azote étaient significativement et positivement corrélées avec l'index de qualité de site (valeurs de $\mathrm{R}^{2}$ de $0,86,0,90$ et 0,84 respectivement). Nous proposons qu'à partir de tests futurs plus raffinés, une mesure des particules fines de matière organique peut être utilisée pour prédire de manière précise la quantité disponible en azote au sein des aménagements en milieu urbain. Cette recherche démontre que les aménagements en milieu urbain sont plutôt variables en terme de disponibilité en azote. En raison de cette variabilité, nous recommandons que els aménagements en milieu urbain soient évalués sur la base de sites individuels afin de gérer correctement l'azote.

Zusammenfassung. Um in der Baumpflege einen Stickstoffdüngeplan zu entwickeln, haben wir organisches Material, mikrobielle Biomasse und Kohlen- und Stickstoffmineralisation mit der Absicht studiert, den pflanzenverfügbaren Stickstoff unter einer Reihe von Landschaftsbedingungen zu charakterisieren. Fraktionen von feiner, partikulärer organischer Masse (POM) wurden deutlich mit mikrobieller Masse, Kohlenstoffmineralisation und Stickstoffmineralisation. Diesen urbanen Landschaften wird ein Standortqualitätsindex basierend auf Landschaftsalter und Managementpraxis zugeteilt. Feine POM, mikrobielle Biomasse $\mathrm{N}$ und Stickstoffmineralisation wurden deutlich und positiv mit dem Standortqualitätsindex korreliert. Wir schlagen vor, dass mit Verfeinerung und weiterem Testen eine POM-Messung genutzt werden kann, um akkurat die Stickstoffverfügbarkeit in urbanen Landschaften vorherzusagen. Diese Forschung zeigt, dass urbane Landschaften sehr unterschiedlich in Bezug auf Stickstoffverfügbarkeit sind. Wegen dieser Variabilität empfehlen wir, dass urbane Landschaften am Standort für eine genaue Stickstoffdüngung untersucht werden sollten.

Resumen. Con el fin de manejar el nitrógeno en el cuidado de los árboles, se estudió la materia orgánica del suelo, biomasa microbiana y mineralización de carbono y nitrógeno, en un intento para caracterizar el nitrógeno disponible para la planta bajo una variedad de condiciones de manejo de los paisajes. Las fracciones de materia orgánica de las partículas finas (POM) estuvieron significativamente correlacionadas con la biomasa, mineralización del carbono y mineralización del nitrógeno (valores de $\mathrm{R}^{2}$ entre 0.42 a 0.89 ). Estos paisajes urbanos fueron asignados a un índice de calidad de sitio basado en edad y prácticas de manejo. POM fino, bioamasa de $\mathrm{N} \mathrm{y}$ mineralización de $\mathrm{N}$, estuvieron positiva y significativamente correlacionados con el índice de calidad de sitio (valores de $\mathrm{R}^{2}$ de 0.86 , 0.90 y 0.84 , respectivamente). Se propone que con el refinamiento y pruebas futuras, las mediciones de POM fino puedan ser utilizadas para predecir con precisión la disponibilidad de nitrógeno del suelo en ambientes urbanos. Esta investigación enseña que los paisajes urbanos son variables en términos de disponibilidad de nitrógeno. Debido a esa variabilidad se recomienda que los paisajes urbanos sean evaluados por sitio para un apropiado manejo del nitrógeno. 